\title{
Tobacco cessation: Role of oral medicine expert
}

\author{
Priya Agarwal ${ }^{1, *}$, Amit Mhapuskar ${ }^{2}$, Darshan Hiremutt ${ }^{3}$, Shams-UL-Nisa ${ }^{4}$, Versha Rani Giroh ${ }^{5}$ \\ 1,5Post Graduate Student, ${ }^{2}$ Professor \& HOD, ${ }^{3}$ Assistant Professor, ${ }^{4}$ Associate Professor, Dept. of Oral Medicine and Radiology, \\ Bharati Vidyapeeth (Deemed to be University) Dental College and Hospital, Pune, Maharashtra, India
}

*Corresponding Author:

Email: drpriya.agarwal10@gmail.com

\begin{abstract}
Introduction: Tobacco is the single most important avoidable cause of premature morbidity and mortality in the world. Tobacco dependence is a chronic condition that often requires repeated interventions. Since oral medicine experts are the first to note any changes that can occur in the oral cavity, they can play a major role in its prevention and intervention. There are well-tried and cost-effective methods for interventions. An oral medicine expert can play an effective role in tailoring a special and specific cessation programme for every individual to improve quit rate and prevent relapse.
\end{abstract}

Objective: This review is prepared with the objective to help Oral Medicine Experts to guide differential prescribing practices and tailoring pharmacotherapy for tobacco cessation.

Conclusion: Interventions by Oral Medicine Experts have been found to be effective in helping people to quit tobacco.

Keywords: Tobacco dependence, tobacco cessation, oral medicine expert, nicotine replacement therapy.

\section{Introduction}

Tobacco is the single most important avoidable cause of premature morbidity and mortality in the world. The World Health Organization (WHO) has estimated that there are about 1100 million smokers worldwide, which represents about one-third of the global population aged over 15 years. About $73 \%$ of smokers are in developing countries, and in industrialized countries there are about 200 million male smokers and 100 million female smokers. In the 15 -year-old population of developing countries, it is estimated that about $48 \%$ of males and $7 \%$ of females are smokers. ${ }^{1}$

In India, tobacco consumption is responsible for half of all the cancers in men and one fourth of all cancers in women. ${ }^{2}$ India also has one of the highest rates of oral cancer in the world, partly attributed to the high prevalence of tobacco chewing. ${ }^{3-6}$

The Global Adult Tobacco Survey (2016-17) estimated that $28.6 \%$ of adults aged 15 and above (26.7 crore) use tobacco in some form. 19.9crore adults in rural areas and 6.8 crore adults in urban areas use tobacco. $^{7}$

\section{Tobacco and Mortality}

Most malignancies of the upper aero digestive tract are squamous cell carcinomas (SCC) arising in the mucous membrane of the mouth, pharynx, and larynx and share common risk factors. ${ }^{8}$

For both genders combined, cancer of the mouth and pharynx ranks sixth overall in the world, behind lung, stomach, breast, colon and rectum, and cervix plus corpus uteri. Mouth and pharynx are third most common site for males in developing countries and fourth among females. The highest rates in the world for oral cancer are found in France, the Indian subcontinent, Brazil, and central/eastern Europe.

\section{Tobacco Cessation Practices}

The tobacco use exerts detrimental effects on dental treatment and oral health. Various dental organizations around the world have recommended the cessation of tobacco use. At a global level, an advocacy guide for oral health professionals included smoking cessation practice (FDI/WHO, 2005) ${ }^{9}$

There are two types of modalities for tobacco cessation:

1. Non-Pharmacotherapy

2. Pharmacotherapy

I. Nicotine Replacement Therapy (NRT)

II. Non-Nicotine Replacement therapy

III. Nicotine vaccine

\section{Non-Pharmacotherapy}

The 5 "A" S, 5 "R" $S \& 5$ "D" $S$

The Five A's (Ask, Advise, Assess, Assist and Arrange), Five R's (Relevance, Risk, Rewards, Repetitions, Roadblocks) and five 'D's (Delay, Distract yourself, Drink water, Deep breath, Discuss your feelings) is a five to fifteen minute research based counseling approach that has proven global success (Table 1). ${ }^{10-11}$

Table 1

\begin{tabular}{|l|l|l|}
\hline \multicolumn{1}{|c|}{$\mathbf{5}$ “A” } & \multicolumn{1}{c|}{$\mathbf{5}$ “R” } & \multicolumn{1}{c|}{ 5 “D” } \\
\hline Ask & Relevence & Delay \\
\hline Advise & Risks & Distract yourself \\
\hline
\end{tabular}




\begin{tabular}{|l|l|l|}
\hline Assess & Rewards & Drink water \\
\hline Assist & Road block & Deep breath \\
\hline Arrange & Repetition & $\begin{array}{l}\text { Discuss Your } \\
\text { Feelings }\end{array}$ \\
\hline
\end{tabular}

\section{Pharmacotherapy ${ }^{12}$}

Medications are important and effective tools for increasing cessation success by relieving nicotine craving and withdrawal symptoms. There are currently seven FDA-approved tobacco cessation medications available that increase long-term tobacco use quit rates. These treatments are listed in the chart below and are available either by prescription or over-the-counter (OTC).

Table 2: Therapy recommended for quitting tobacco depending on level of addiction ${ }^{13}$

\begin{tabular}{|l|l|}
\hline \multicolumn{1}{|c|}{$\begin{array}{c}\text { Level of } \\
\text { Addiction }\end{array}$} & \multicolumn{1}{c|}{ Recommended Therapy } \\
\hline Light Addiction & Behavioral Intervention/NRT \\
\hline $\begin{array}{l}\text { Moderate } \\
\text { Addiction }\end{array}$ & $\begin{array}{l}\text { Behavioral Intervention/NRT/ } \\
\text { Pharmacological Therapy }\end{array}$ \\
\hline $\begin{array}{l}\text { Serious } \\
\text { Addiction }\end{array}$ & $\begin{array}{l}\text { Behavioral Intervention/NRT/ } \\
\text { Pharmacological therapy/ } \\
\text { professional and Intensive }\end{array}$ \\
\hline
\end{tabular}

Behavioral Therapy

\section{Assessment of level of addiction ${ }^{14}$}

Qualitative methods: The simplest approach to measuring dependence on cigarettes is a basic qualitative approach that uses questions to find out whether the smoker has difficulty in refraining from smoking in circumstances when he or she would normally smoke or whether the smoker has made a serious attempt to stop in the past but failed.

Quantitative methods: The most commonly used quantitative measure of dependence is the Fagerstrom test for nicotine dependence, which has proved successful in predicting the outcome of attempts to stop. The higher the score on this questionnaire, the higher the level of dependence: smokers in the general population score an average of about 4 on this scale.

Objective methods: The concentration of nicotine or its metabolite, cotinine, in blood, urine, or saliva is often used in research as an objective index of dependence because it provides an accurate measure of the quantity of nicotine consumed, which is itself a marker of dependence.

Table 3: Pharmacotherapy for tobacco cessation ${ }^{15}$

\begin{tabular}{|c|c|c|c|}
\hline Drug & Dose & $\begin{array}{c}\text { Side effect/Drug } \\
\text { interactions }\end{array}$ & Comments \\
\hline $\begin{array}{l}\text { NRT: sustained } \\
\text { release } \\
\text { Nicotine } \\
\text { Transdermal } \\
\text { patch } \\
\text { (Nicodem CQ) }\end{array}$ & $\begin{array}{l}20 \text { cigarettes/day: } 1 \text { patch } \\
(21 \mathrm{mg} / 24 \mathrm{~h} \text { ) for } 4-6 \text { weeks, } \\
\text { then taper to } 14 \mathrm{mg} / \mathrm{day} \text { for } \\
2-4 \text { weeks, then } 7 \mathrm{mg} \text { per } \\
\text { day for } 2-4 \text { weeks } \\
\text { If patient has } \\
\text { cardiovascular disease, } \\
\text { weighs less than } 45 \mathrm{~kg} \text { or } \\
\text { smokes, } \mathrm{K} \text { pack/day begin } \\
\text { with } 14 \mathrm{mg} / 24 \mathrm{~h} 66 \text { weeks } \\
\text { then Q to } 7 \mathrm{mg} / 24 \mathrm{~h} 62 \\
\text { weeks } 62 \\
\text { NB: 16-h patches are } \\
\text { available in some } \\
\text { countries }\end{array}$ & $\begin{array}{l}\text { Side effects: Skin } \\
\text { sensitivity and irritation } \\
\text { (most common);nausea, } \\
\text { dyspepsia }\end{array}$ & $\begin{array}{l}\text { Start patch on quit date. } \\
\text { Advice not to smoke } \\
\text { cigarettes while using the } \\
\text { patch, though this is } \\
\text { generally safe and does not } \\
\text { indicate treatment failure. } \\
\text { Educate users on the signs } \\
\text { and symptoms of nicotine } \\
\text { toxicity }\end{array}$ \\
\hline $\begin{array}{l}\text { NRT: } \\
\text { immediate } \\
\text { release } \\
\text { Nicotine } \\
\text { inhaler } \\
\text { (Nicorette) }\end{array}$ & $\begin{array}{l}\text { Available in } 4 \mathrm{mg} \text { strength. } \\
\text { Encourage patient to use at } \\
\text { least six doses/day for the } \\
\text { first } 3-6 \text { weeks. } \\
\text { Max } 12 / \text { day. } \\
\text { Tapering: gradual } \\
\text { reduction in use over next } \\
6-12 \text { weeks, stopping } \\
\text { when reduced to 1-2/day }\end{array}$ & $\begin{array}{l}\text { Side effects: Mild local } \\
\text { irritation of mouth and } \\
\text { throat, coughing, rhinitis } \\
\text { that may decline with } \\
\text { continued use }\end{array}$ & $\begin{array}{l}\text { Not a true inhaler-the } \\
\text { nicotine is delivered and } \\
\text { absorbed buccally. } \\
\text { "Hand-mouth" activity } \\
\text { from using the inhaler is } \\
\text { preferred by some quitters } \\
\text { while others and to be a } \\
\text { trigger. Useful in those } \\
\text { with poor oral health or } \\
\text { dentures and in those who } \\
\text { cannot chew gum. }\end{array}$ \\
\hline $\begin{array}{l}\text { NRT: } \\
\text { Immediate }\end{array}$ & $\begin{array}{lccc}10-12 & \text { pieces } & \text { per } & \text { day } \\
\text { initially } & (2 \mathrm{mg} & \text { or } & 4 \mathrm{mg}\end{array}$ & $\begin{array}{lr}\begin{array}{l}\text { Side effects: } \\
\text { soreness, }\end{array} & \begin{array}{r}\text { Mouth } \\
\text { hiccups, }\end{array}\end{array}$ & $\begin{array}{l}\text { Use 4mg in heavily } \\
\text { dependent somokers. May }\end{array}$ \\
\hline
\end{tabular}




\begin{tabular}{|c|c|c|c|}
\hline $\begin{array}{l}\text { release } \\
\text { Nicotine gum } \\
\text { (Nicotex) }\end{array}$ & $\begin{array}{l}\text { pieces) to maximum of } 20 \\
\text { pieces per day, for } 12 \\
\text { weeks. } \\
\text { Tapering: } 1 \text { piece/day each } \\
\text { week, as withdrawal } \\
\text { symptoms allow }\end{array}$ & dyspepsia, jaw ache & $\begin{array}{l}\text { be used for temporary } \\
\text { abstinence- e.g. To comply } \\
\text { with smoking restrictions } \\
\text { on aeroplanes. }\end{array}$ \\
\hline $\begin{array}{l}\text { NRT: } \\
\text { immediate } \\
\text { release } \\
\text { Nicotine } \\
\text { lozenge } \\
\text { (Nicorette) }\end{array}$ & $\begin{array}{l}1 \text { lozenge (2mg or } 4 \mathrm{mg} \\
\text { lozenges) every } 1-2 \mathrm{~h} \text { up to } \\
6 \text { weeks; weeks } 7-9 \text { every } \\
2-4 \mathrm{~h} \text {; weeks } 10-12 \text {, every } \\
4-8 \mathrm{~h}\end{array}$ & $\begin{array}{l}\text { Side effects: Nausea, } \\
\text { hiccups, } \\
\text { heartburn, } \\
\text { headache, coughing. }\end{array}$ & \\
\hline $\begin{array}{l}\text { NRT: } \\
\text { immediate } \\
\text { release } \\
\text { Nicotine nasal } \\
\text { spray } \\
\text { (Nicorette) }\end{array}$ & $\begin{array}{l}1.0 \mathrm{mg} \text { of nicotine per } \\
\text { spray (10ml bottle } \\
\text { contains } 100 \mathrm{mg} \text { nicotine }) \\
1-2 \text { doses } / \mathrm{h} \text { up to } 40 \text { doses } \\
\text { per day; for } 3 \text { months }\end{array}$ & $\begin{array}{l}\text { Side effects: } \\
\text { nasal/throat irritation }\end{array}$ & \\
\hline $\begin{array}{l}\text { Antidepressant: } \\
\text { Bupropion }\end{array}$ & $\begin{array}{l}\text { 150mg daily 63days then } \\
150 \mathrm{mg} \text { twice daily } 67-12 \\
\text { weeks. Begin } 1-2 \text { weeks } \\
\text { before the selected quit } \\
\text { date }\end{array}$ & $\begin{array}{l}\text { Side effects: Insomnia, dry } \\
\text { mouth }\end{array}$ & $\begin{array}{l}\text { Not recommended in } \\
\text { patients with conditions } \\
\text { predisposing to seizures, } \\
\text { history of seizures, current } \\
\text { eating disorder or severe } \\
\text { hepstic impsirment. Least } \\
\text { expensive of or } \\
\text { medications indicated for } \\
\text { smoking cessation. }\end{array}$ \\
\hline $\begin{array}{l}\text { Nicotine } \\
\text { receptor partial } \\
\text { agonists } \\
\text { Varenicline }\end{array}$ & $\begin{array}{l}0.5 \mathrm{mg} \text { daily for } 3 \text { days, } \\
\text { then twice daily for } 4 \text { days } \\
\text { then } 1 \mathrm{mg} \text { by mouth twice } \\
\text { daily for } 12 \text { weeks. } \\
\text { Patient should quit } \\
\text { smoking } 1-2 \text { weeks after } \\
\text { starting the medication. } \\
\text { Reassess if patient is still } \\
\text { smoking } 4 \text { weeks after } \\
\text { starting medication; can be } \\
\text { continued for an additional } \\
12 \text { weeks if patient has } \\
\text { benefited. No tapering } \\
\text { necessary. }\end{array}$ & $\begin{array}{l}\text { Side effects: nausea, sleep } \\
\text { disturbance, } \\
\text { abnormal/vivd/strange } \\
\text { dreams. } \\
\text { Drug interactions: should } \\
\text { not be combined with } \\
\text { NRT therapy because of } \\
\text { increased risk of adverse } \\
\text { effects }\end{array}$ & $\begin{array}{l}\text { Does not induce } \\
\text { cytochrome P450 } \\
\text { enzymes; excreted renally } \\
\text { unchanged. } \\
\text { Smokers considering use } \\
\text { of varenicline should be } \\
\text { screened for a history of } \\
\text { psychiatric disorders, have } \\
\text { close monitoring and be } \\
\text { advised to report any } \\
\text { adverse effects they might } \\
\text { experience. Care and close } \\
\text { surveillance needs to be } \\
\text { taken if prescribing to } \\
\text { patients with psychiatric } \\
\text { disorders. }\end{array}$ \\
\hline
\end{tabular}




\section{Chart 1: Algorithm for tailoring pharmacotherapy for smoking cessation ${ }^{16}$}

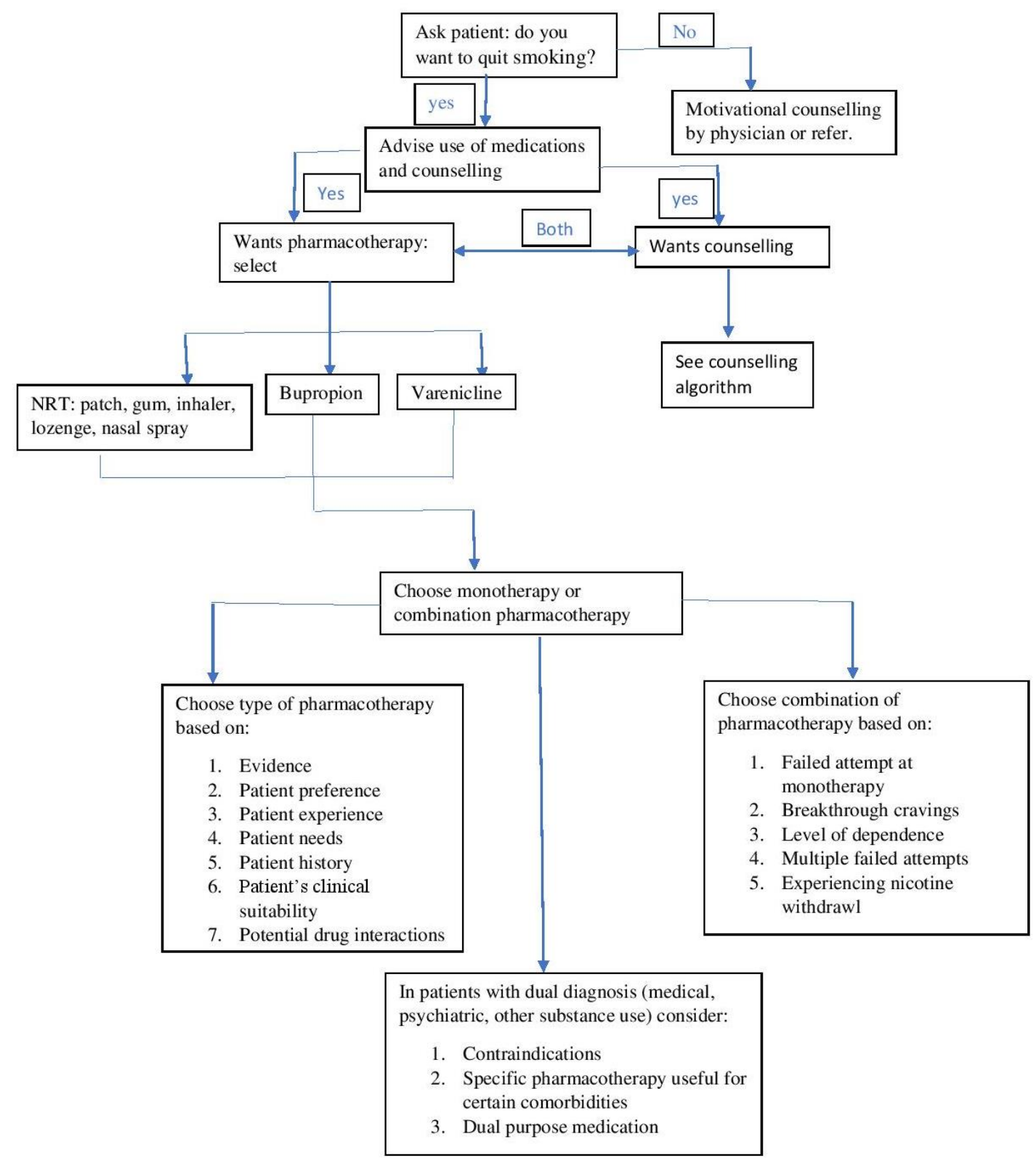

\section{Combination Medications}

A number of combinations of medications are also effective in improving quitting success, and using two types of tobacco cessation medications simultaneously can improve quit rates when compared with one medication. Combination therapy or high-dose nicotine replacement therapy (NRT) may be suitable for those who are highly nicotine dependent or have a history of severe withdrawal symptoms.

The following combination therapies are effective in increasing quit rates.

1. Long-term nicotine patch + other NRT product (gum or spray)

2. Nicotine patch + nicotine inhaler

3. Nicotine patch + Bupropion SR

\section{Treatment Options}

It is important to provide wide range of treatment options, as success with particular methods varies among individuals. The process of quitting usually involves several attempts, the different types of cessation medications are used before achieving success. The combination of medications and counselling is more effective than use of either method alone.

\section{Role of Oral Medicine Expert}

An ideal tobacco use cessation programme must be individualised, that should account for the reasons a person uses tobacco, the environment in which the use occurs, available resources to quit and individual preferences about how to quit. The clinician should 
always bear in mind that cessation can be very difficult to achieve, and it is important to be patient and persistent in developing, implementing and providing each patient with an individual cessation-programme. ${ }^{17}$

There is increasing evidence that the success of any tobacco use cessation strategy or effort cannot be divorced from the health care system in which it is embedded. Several behavioural and pharmacologic interventions are recognised as having high levels of supporting evidence of effect. ${ }^{34}$ These include counselling by various health care providers including oral health professionals, nicotine replacement and bupropion therapies. High levels of evidence means that there are 'multiple well-designed randomised clinical trials, directly relevant to the recommendation that yield a consistent pattern of findings'. Indeed, the data are compelling that pharmacological and counselling treatment each independently boost cessation success. ${ }^{18}$

The oral medicine expert can use any of the above mentioned methods for assessment of nicotine dependence of patient and tailor the cessation programme accordingly.

Tobacco use cessation (TUC) in dentistry is critical for reducing the effect of a major risk factor for both oral and systemic diseases. ${ }^{17}$ Oral medicine experts (particularly dentists and dental hygienists but also including other dental care professionals) may see their patients on a frequent and recurring basis.

Behavioural counselling interventions in clinical settings are an important means of addressing prevalent health-related behaviours, such as lack of physical activity, poor diet, substance (tobacco, alcohol, and illicit drug) use and dependence, and risky sexual behaviour. In the dental setting, this may be viewed in a similar context. ${ }^{18}$

Motivational interviewing (MI) is a style of behaviour change counselling (motivational enhancement therapy) developed originally to prepare patient's goals and encourages them to reach those goals. It was applied for the first time to tobacco cessation practices in 1998, in a hospital emergency room with adolescents. ${ }^{19}$

Oral Medicine Expert have many opportunities and play an important role to reduce the prevalence of tobacco use and promoting tobacco cessation. Even so, tobacco cessation activities do not play a prominent role in dental practice. An estimated $50 \%$ of smokers visit a dentist annually which gives them the opportunity to associate cessation advice with readily visible changes in the oral status. Therefore, the dental office may be ideally suited to help patients quit smoking. ${ }^{17}$

\section{Supportive therapy, follow-up and relapse prevention $^{20}$}

Dentist must consider supportive therapy for use on a case - by - case basis after first line medications (either alone or in combination).
Tobacco users, who have recently quit, face a high risk of relapse. Although most relapse occurs early in quitting process, some relapse occurs months or even years after the quit date. The best strategy for producing high long-term abstinence rates appears to be the use of the most effective cessation medication during the quit attempt and providing practical advice and motivation in each visit. The first prescription is advised for at least 15 days, making it a point to emphasize the total duration therapy, follow up with the patient should be. First month: weekly contact, 2nd and 3rd months: monthly and for rest of first year: quarterly.

\section{Conclusion}

Tobacco smoking and chewing is one of the prime factors responsible for oral pre-cancer and cancer. The incidence and prevalence of such lesions in South Asian countries like India is high owing to the increased production and consumption of tobacco. The relative lack of awareness regarding the harmful effects of tobacco is a major reason for the same. Preventive measures should begin at grass root levels aimed at individuals who are at high risk for tobacco usage along with intervention at community level and policy level interventions by the concerned policy makers. Oral Medicine Experts should play an active role in prevention and control of tobacco induced lesions due to the direct contact with patients who are at increased risk.

\section{References}

1. Memon A, Moody PM, Sugathan TN, El-Gerges N, alBustan M, al-Shatti A, al-Jazzaf H. Epidemiology of smoking among Kuwaiti adults: prevalence, characteristics, and attitudes. Bulletin of the World Health Organization. 2000 Nov;78(11):1306-15.

2. Rani M, Bonu S, Jha P, Nguyen SN, Jamjoum L. Tobacco use in India: prevalence and predictors of smoking and chewing in a national cross sectional household survey. Tobacco control. 2003 Dec 1;12(4):e4.

3. Jindal SK, Aggarwal AN, Chaudhry K, Chhabra SK, D Souza GA, Gupta D, Katiyar SK, Kumar R, Shah B, Vijayan VK. Tobacco smoking in India: prevalence, quitrates and respiratory morbidity. Indian Journal of Chest Diseases and Allied Sciences. 2006 Jan 18;48(1):37.

4. Franceschi S, Bidoli E, Herrero R, Munoz N. Comparison of cancers of the oral cavity and pharynx worldwide: etiological clues. Oral oncology. 2000 Jan 31;36(1):10615.

5. Moore SR, Johnson NW, Pierce AM, Wilson DF. The epidemiology of tongue cancer: a review of global incidence. Oral diseases. 2000 Mar 1;6(2):75-84.

6. Dikshit RP, Kanhere S. Tobacco habits and risk of lung, oropharyngeal and oral cavity cancer: a population-based case-control study in Bhopal, India. International Journal of epidemiology. 2000 Aug 1;29(4):609-14.

7. According to WHO.

8. Muir C, Weiland L. Upper aerodigestive tract cancers. Cancer. 1995 Jan 1;75(S1):147-53.

9. Patel P, Patel V. Oral mucosal lesions among residence of a town in north Gujarat. Natl J Med Res. 2011;1(1):3-6.

10. Jha $P$, Ramasundarahettige $C$, Landsman V, Rostron B, Thun M, Anderson RN, McAfee T, Peto R. 21st-century 
hazards of smoking and benefits of cessation in the United States. New England Journal of Medicine. 2013 Jan 24;368(4):341-50.

11. Hanioka T, Ojima M, Tanaka H, Naito M, Hamajima N, Matsuse R. Intensive smoking-cessation intervention in the dental setting. Journal of dental research. 2010 Jan 1;89(1):66-70.

12. McCuller WJ, Sussman S, Wapner M, Dent C, Weiss DJ. Motivation to quit as a mediator of tobacco cessation among at-risk youth. Addictive Behaviors. 2006 May 31;31(5):880-8.

13. Pai A, Prassad S. Attempting tobacco cessation. An oral physician's perspective. Asian Pacific J Cancer Prev. 2012;13:4973-7.

14. West R. ABC of smoking cessation:Assessment of dependence and motivation to stop smoking. BMJ. 2004;328-9.

15. Fiore MC, Jae'n CR, Baker TB, et al. Treating tobacco use and dependence: 2008 update. Rockville, MD: US Department of Health and Human Services, 2008. Available at http://www.surgeongeneral.gov/tobacco/treating_tobacc_ use08.pdf.

16. Selby P. Smoking cessation. In: Gray J, ed. Therapeutic choices, 5th ed. Ottawa,Ontario: Canadian Pharmacist Association, 2007.

17. Bernard Le Foll MD PhD, Tony P. George MD

Treatment of tobacco dependence: integrating recentprogress into practice. CMAJ 2007;177(11):137380

18. Llewellyn CD, Johnson NW, Warnakulasuriya KA. Risk factors for squamous cell carcinoma of the oral cavity in young people - a comprehensive literature review. Oral oncology. $2001 \mathrm{Jul}$ 31;37(5):401-18.

19. Jiloha RC. National Tobacco Control Programme. Delhi Psychiatry Journal. 2010;13(2).

20. Jepson RG, Harris FM, Platt S, Tannahill C. The effectiveness of interventions to change six health behaviours: a review of reviews. BMC public health. 2010 Sep 8;10(1):1.

21. Richmond RL. Multivariate models for predicting abstention following interventions to stop smoking by general practitioners. Addiction. 1993;88:1127-35. 